\title{
Self-reflective dramaturgy in Rossini's comic operas
}

\author{
Maria Birbili \\ (Freie Universität Berlin)
}

\begin{abstract}
My article discusses Rossini's comic operas by investigating the specific means with which humour, in the way of comedy, parody, and ironic distance is achieved by Rossini and his librettists. In addition to the traditional use of comedic techniques with a direct provenance in the spoken theatre or in the commedia del arte (such as verbal repetition, puns, and slapstick), I discuss how Rossini uses self-reflective techniques in the plot devices, the dramatic situations, and particularly in his deliberate use of specific formal structures in the music which either intensify or completely negate the dramatic situation at hand. More specifically with the use of crescendo, sonata form, and the deliberate slowing down of dramatic action in a critical dramatic situation through repetitive vocal embellishments for comic relief, while even the characters on stage self-reflectively complain about this. This selfreflective dramaturgy exploits the dynamic between com-poser, performers, and audience, and creates new possibilities in interdependence between the deliberate use of artifice and the detection and appreciation of artifice by the audience. The selfreflection results in presenting the dramatic situation and its musical setting as a metacomment on the traditional formal structures of Italian opera itself.
\end{abstract}

Keywords: Rossini, artifice, self-reflection, meta-commentary 
My article will examine the issue of humour in Rossini's opere buffe and farse by investigating the specific means with which humour, in the way of comedy, parody, ironic distance, and even with what we today call "camp" is achieved by Rossini and by his librettists. In addition to the traditional use of comedic techniques with a direct provenance in the spoken theatre (such as verbal repetition and puns in the text), or in the commedia del arte (such as physical puns and slapstick), I'm interested in seeing how Rossini uses specific self-reflective techniques in the plot devices, the dramatic situations, and particularly in his deliberate use of specific formal structures in the music, which either intensify or completely negate the dramatic situation at hand. More specifically, the use of crescendo, sonata form, the "frozen ensemble", the pseudo-canon, and the deliberate slowing down of dramatic action through repetitive vocal embellishments in an otherwise critical dramatic situation are known to have been used by Rossini for comic relief in all of his comic operas. In his most famous comic opera, I/ barbiere di Siviglia, one of the characters (Figaro) self-reflectively complains about this phenomenon, as will be discussed later.

Rossini's self-reflective dramaturgy exploits the dynamic between composer, performers, and audience, and creates new possibilities for humour in interdependence between the deliberate use of artifice and the detection and appreciation of artifice by the sophisticated, informed audience. Thus selfreflection results in presenting the dramatic situation and its musical setting as a meta-comment about the traditional formal structures of Italian opera itself as a genre.

The self-referentiality of the genre of Italian opera buffa has its provenance in at least as early as the $18^{\text {th }}$ century, a famous example being Mozart's Don Giovanni quoting other contemporary works inside of its Finale II, such as La cosa rara, I litiganti, and the com-poser's own Figaro, as well as playfully imitating several motivic materials from Giuseppe Gazzaniga's // convitato di pietra, the Don Giovanni precursor.

Self-referentiality occurs both in the libretto and in the music. In addition to this, Rossini's customary practice of self-borrowings between his different works 
resulted in a fascinating self-referential intertextuality between works that essentially had little to do with each other. To give an example: When Gertrude Righetti-Georgi, the mezzo-soprano creator of the female protagonist in // barbiere di Siviglia, became fond of the tenor's elaborate aria in the end of I/ barbiere, "Cessa di più resistere" \{ "Stop resiting" $\}$ and snatched it for herself, both for II barbiere di Siviglia and for La Cenerentola, her decision bore immediate consequences into the music lesson scene in Act II of II barbiere di Siviglia, where a virtuoso aria for the female protagonist had to be cut or replaced for the prima donna to either keep her strength or to have a foreign, easy aria inserted at that place as a soloistic number, since she would be facing the virtuoso "Cessa di più resistere" at the end of the opera. After a few years, the "stolen aria" was perceived as authentic in La Cenerentola, in the form of the famous rondo "Non più mesta accanto al fuoco" " "No longer will I be sitting by the fire, miserable" $\}$. Thus when soprano Fanny Ekerlin reinserted "Non più mesta" into // barbiere di Siviglia in 1827, it was inserted in the version used in La Cenerentola and it was perceived as a completely alien element in // Barbiere, despite having its initial, authentic provenance from there. Similar cases of non-intentional selfreferentiality due to self-borrowings will be discussed in my book.

Pertaining to formal structure as a means for comic relief, Philip Gossett has been criticized for noticing that the unnecessarily long aria Bartolo's "A un dottor della mia sorte" " "For a doctor as important as myself" $\}$ in // barbiere di Siviglia is based on an ironic use of sonata form, as the single piece set in sonata form in the entirety of Rossini's operas, as a sign of the pedantry and stub-borness of the old tutor.' This interpretation has been met with the criticism that apparently no one was supposed to know about sonata form in 1816, when this aria was composed and exchanged against the initial, non authentic, shorter and much more conventional aria Bartolo's "Manca un foglio" \{"There's a page missing"' \}. Yet Rossini, a great admirer of Mozart, was most certainly acquainted with sonata form as proven in the Ouvertures of his operas, despite the fact that obviously no other among composers was using this specific formal design in the

${ }^{1}$ This has been discussed in presentations on // Barbiere di Siviglia at the Chicago Lyric Opera and at the Santa Fe Festival. 
genre of opera. In relation to this phenomenon, I have located a quote by French philosopher and dramatist Bernard le Bouvier de Fontenelle complaining "Sonate, que me veux-tu?" ${ }^{2}$ which reflects on the exact same situation as in the aria for Bartolo.

I/ barbiere di Siviglia exemplifies a crucial stage in Rossini's œuvre as both a point of arrival in Rossini's evolution as a composer of comic operas and as the culmination and, in some respects, the conclusion of the history of Italian comic opera in a general sense. The plot of the opera and the play by French playwriter Beaumarchais on which it is based, with their roots in the world of the Italian improvised theatre known as the commedia dell'arte, are enriched by the musical forms and techniques Rossini employs in this work, developed from eighteenthcentury practice, but stamped with Rossini's own remarkable individuality and the fascinating world of mirroring and self-references that specifically characterize this work, as Rossini keeps providing subtle hints of the composer being present behind the scenes. The above factors made me decide to concentrate this article mainly on // barbiere di Siviglia.

The Introduzione of // barbiere di Siviglia contains the self-borrowed chorus in honor of Osiris from Rossini's opera seria Aureliano in Palmira (a work which, as a by the by, also provided the Ouverture for I/ barbiere di Siviglia). Interestingly enough, both pieces (the Sinfonia and the opening chorus), even if not authentic, appear better fitted in // barbiere di Siviglia than in Aureliano in Palmira!

Rossini embedded Count Almaviva's/Garcías's Cavatina (entrance aria) for which famou tenor Manuel García himself provided the guitar accompaniment, (since García's hand is suspected to be present in the autograph score of the opera). The Barbiere Introduzione consists of an opening section ("Piano, pianissimo, tutto è silenzio" \{ "Hush, hush, let us stay silent" $\}$ which contains

\footnotetext{
2 Bernard Le Bouyer de Fontenelle, as reported by Jean-Jacques Rousseau in an article in his Encyclopédie. “Je n'oublierai jamais le mot du célèbre $M$. de Fontenelle, qui, se trouvant à un concert, excédé par cette symphonie éternelle s'écria dans un transport d'impatience: "Sonate, que me veux-tu?". In: "Sonate", Encyclopédie ou Dictionnaire raisonné des sciences, des arts et des métiers par une Société de Gens de lettres, (ed.) Denis Diderot and Jean le Rond d'Alembert, vol. 15, Paris 1765, p. 348.
} 
dialogue, solo, chorus, the inserted Cavatina Almaviva's with the atypical reaction of the female protagonist not with an entrance aria, but with a short, echo-like perticchino participation in her admirer's refrain. Then the opening section of the Introduzione is repeated in a conclusion in which the chorus receives payment by the Count, and they all explode in profound gratitude, thanking the Count Almaviva for having been abundantly generous to them with his money. Obviously here the formal musical structure of the stretta (the closing section) of this Introduzione is at odds with the protagonist's intentions, as Count Almaviva is greatly annoyed by the noisy stretta, with its structurally necessary repeat, its crescendos, cadential phrases, etc., as it is exactly the situation he wants to avoid, for fear that the servants or the tutor of his beloved hear the noise and turn up on the stage to obstruct him from further communicating with her. Clearly, the comic relief produced by this scene lies not just in the fact that the clueless, naïve chorus is noisy when it has to be quiet and discreet, and in the fact that Count Almaviva and the comprimario secon-dary character Fiorello react with abuse to the chorus' thankful mini-strations ("Basta, basta, zitti, zitti, ahi canailla, via di qua") \{"Enough, enough, shut up, shut up, get the hell out of here, canailles"\} but, additionally, a more sophisticated comedic device is produced by the fact that the noisy situation is primarily and essentially controlled by the musical formal structure of Italian opera necessary for the traditional conclusion of a stretta. Thus the dramatic situation is intentionally presented as operating completely against what the musical structure requires, creating a disassociation between form and content, which is what makes the whole situation on the stage even more hilarious for an informed, sophisticated audience, clued-up and educated in the genre of Italian opera.

Rossini also famously used the crescendo in a more literal sense in his well-known aria for Basilio "La calunnia" \{"The art of diffamation"\}, which is a musical piece built solely on the idea of the crescendo, both in the libretto text and in the music, which in this case function in perfect connection and contextualisation - without us having to ask which comes first, la musica o le parole. ${ }^{3}$

3 This is the infamous title of a farsa by Antonio Salieri and Giovanni Battista Casti, composed in Vienna in 1786. 
A similar but much stronger interplay in self-referentiality and ironic distance between content and form for the genre of Italian opera occurs in a trio in Act II of // barbiere di Siviglia, when Count Almaviva and Rosina finally make up after her having thought that he was two-timing her with another woman. They celebrate their reconciliation and mutual feelings for each other while preparing to flee Bartolo's lodgings from the balcony via a ladder provided by the resourceful Figaro. This is a situation so traditionally embedded in the genre of commedia del arte and in the genre of Italian comic opera, that it can't get more cliché. What does Rossini do to differentiate this from the norm? He follows the musical tradition faithfully, as in freezing the music in a traditional pseudo-canon of the enamoured couple, with Almaviva echoing Rosina in lovesick coloratura embellishments. Yet the dramatic situation requires a hasty dealing with the situation at hand, as in using the aforementioned ladder provided by Figaro and fleeing from the premises before they get caught. But what happens instead of fleeing? The music freezes not just once, but twice, following the rules of what the internal structure of Italian opera dictates in the vocal ensembles. Thus when in reality one would think it was time for the protagonists to move on, they don't move at all. Count Almaviva and Rosina freeze in a pseudo-canon of virtuoso coloratura, lost in their feelings of love for each other. The additional comedic device is that Figaro, aware of the precarious situation, reacts and tries to make them hurry up and move on. He does this while confined in the required musical structure, in a third repetition of the lovers' pseudo-canon of virtuoso coloratura. Yet Figaro sings in an ironic fashion, making fun of the lovers' lyrical melos, and providing a comedic, self-reflective commentary which makes the audience distance themselves from the dramatic situation at hand, making the audience aware that they are indeed watching a genre confined by specific rules and making them reflect about the genre of Italian opera instead of simply following the plot.

Interestingly enough, it has frequently been complained that // barbiere di Siviglia lacks real passion, particularly pertaining to the question of love, and that the characters are mechanical and standardized clichés, thus not winning the sympathies of the audience. An intense self-reflection is permanently latent in this 
work, a phenomenon which cannot be compared with the situation in other comic operas by Rossini apart from three of his comic operas that also contain a pronounced self-reflective dramaturgy, such as L'equivoco strava-gante, La pietra del paragone, and II Turco in Italia, which will be discussed $\mathrm{n}$ the conclusion of this article. This certainly constitutes an additional factor for the audience of II barbiere to remain cold and detached emotionally.

To return to the trio in question, Figaro notices a lantern and people approaching and stressfully notifies the lovers, followed by an abrupt harmonic jump. What's to happen? Instead of fleeing, the trio reaches its cabaletta, the final section, unavoidably. Such a piece as a cabaletta requires the theme done twice, including a transition in the middle. And Rossini goes as far as to duplicate it here, engaging Almaviva, Rosina, and Figaro in another (short) pseudo-canon. After coming to rest, they are required to and repeat the entire thing again, concluding into cadences followed by "shhh"s as a reminder to remain quiet, yet this is followed by even bigger, final cadences, which are loud, that is, just the opposite of what they're promising to do. At the end of the piece it turns out that the required formal structure of Italian opera was imposed at the worst possible timing plot-wise. Because when the fleeing protagonists are all done with their singing, they find out that the ladder is gone from the escape route, as the required musical devices have interacted with the plot with catastrophic consequences. No wonder that the audience remains self-conscious of the artistic devices, without losing themselves in the plot as in other opere buffe by Rossini, which are constructed more "literally" in their dramaturgy, approaching the genre of opera semiseria, such as La Cenerentola and L'Italiana in Algeri.

Rossini's La pietra del paragone and I/ Turco in Italia are self-reflective to the point that there is the part of a librettist participating on stage, supposedly composing the opera (in II Turco in Italia) or analysing the action (in La pietra del paragone) in a quasi Pirandellian dramaturgy. But most fascinating of all is the self-reflective mockery of the logistic realities of staging Italian opera as evoked in Rossini's farsa L'equivoco stravagante, where the soprano protagonist is a wannabe (female) poet who in a complicated sequence of events is mistaken by the tenor for being a castrato, a man disguised as a woman seeking to marry 
another man. During their comedic duet in the middle of the opera the tenor is greatly offended by the soprano's advances under these circumstances, mistaking her for a man disguised as a wannabe bride. The opera concludes with the soprano joining the army and singing a military aria en travesti, for the first time in a Rossini opera. A similar military aria en travesti was included by Rossini in La pietra del paragone and (more famously) in L'Italiana in Algeri and in Semiramide (for Arsace). Rossini composed 3 of these military arias for a mezzo-soprano en travesti specifically for Marietta Marcolini, including the final rondo in L'Italiana in Algeri.

In Rossini's farsa // Signor Bruschino there is a trio in the middle of the opera which self-referentialy makes fun of the Anagnorisis ${ }^{4}$ scene in the genre of tragedy and tragic opera, which is a key moment in a play/opera when a character makes a critical discovery about another character (often their enemy) being their parent/sibling, etc. Bruschino jr. has debts from playing cards, and his father wants to disown him or have him forcefully married to a rich girl. The lover of said girl takes Bruschino's jr identity so as to marry his beloved. The trio in the middle of the opera contains a very comedic qui pro quod when the fake Bruschino jr is begging his 'father' for forgivance and the bride's father asks, "Please, Signor, this is your faithful son, please forgive the poor boy, we've done some indiscretions in our youth too!" while Bruschino Sr responds with "Who the hell is this? I don't even know this young man!" and the bride's father and the fake Bruschino jr join in with "Please, Sir, please don't be so cruel, forgive him, accept him again as your son, and give your beloved son a hug!". The juxtaposition of the ironic "Padre?" - "Figlio?" is a direct mockery of the expected vocabulary in the opera seria of Metastasio.

In Part 1 of my upcoming book on Rossini I am discussing more details and examples of the sophisticated self-reflection in the dramaturgy of opera buffa and how it manages to give a commentary on the traditions of Italian opera, both on opera buffa and opera seria.

\footnotetext{
${ }^{4}$ Anagnorisis is ancient Greek for "recognizion".
} 


\section{References}

BASEVI, Abramo. Verdi, Studie sulle opere di Giuseppe Verdi. Firenze: 1859, reprint Bologna: Musica dramatica in Aemiliae Romandiolae civitatibus archivum, 1978.

Encyclopédie ou Dictionnaire raisonné des sciences, des arts et des métiers par une Société de Gens de lettres, (ed.) Denis Diderot and Jean le Rond d'Alembert, vol. 15, Paris: 1765.

POWERS, Harold Stone. "La solita forma" and the uses of convention, in: Acta Musicologica 59 (1987), p. 65-90. Also in: Atti del convegno internazionale in occasione della prima del "Rigoletto" in edizione critica, Vienna 12/13 marzo 1983, Parma: Istituto di Studi Verdiani, e Milano: Ricordi, 1987. 